\title{
Eğitsel Oyun ve İşbirlikli Öğrenmenin 6. Sınıf Öğrencilerinin Akademik Başarılarına, Sosyal Becerilerine ve Öğrenme Motivasyonlarına Etkisi
}

\section{The Effect of Educational Games and Cooperative Learning on Students Academic Achievements, Social Skills and Learning Motivations}

\author{
Emre Yıldız ${ }^{\mathrm{a}, *}$, Özlem Ağgül ${ }^{\mathrm{b}}$, Şeyma Çalıklar ${ }^{\mathrm{c}}$, Ümit Şimşek ${ }^{\mathrm{d}}$ \\ ${ }^{a}$ Arş. Gör. Dr., Atatürk Üniversitesi, Kazım Karabekir Eğitim Fakültesi, Matematik ve Fen Bilimleri Eğitimi Bölümü, 25040, Erzurum/Türkiye. \\ ORCID: 0000-0001-6396-9183 \\ ${ }^{\text {b }}$ Atatürk Üniversitesi, Kazım Karabekir Eğitim Fakültesi, Matematik ve Fen Bilimleri Eğitimi Bölümü, 25040, Erzurum/Türkiye. \\ ORCID: 0000-0002-2185-2478
}

${ }^{c}$ Arş. Gör., Atatürk Üniversitesi, Kazım Karabekir Eğitim Fakültesi, Matematik ve Fen Bilimleri Eğitimi Bölümü, 25040, Erzurum/Türkiye. ORCID: 0000-0003-2916-7755

${ }^{\text {d }}$ Prof. Dr., Atatürk Üniversitesi, Kazım Karabekir Eğitim Fakültesi, Matematik ve Fen Bilimleri Eğitimi Bölümü, 25040, Erzurum/Türkiye. ORCID: 0000-0003-2010-9321

\section{MAKALE BİLGISİ}

Makale Geçmişi:

Başvuru tarihi: 07 Ocak 2020

Düzeltme tarihi: 09 Mayıs 2020

Kabul tarihi: 14 Maysi 2020

Anahtar Kelimeler:

Akademik başarı,

Eğitsel oyun,

İsbirlikli öğrenme,

Motivasyon,

Sosyal beceri

\section{ARTICLE INFO}

\section{Article history:}

Received 07 January 2020

Received in revised form 09 May 2020

Accepted 14 May 2020

\section{Keywords:}

Academic achievement,

Educational game,

Cooperative learning,

Motivation,

Social skill
ÖZ

Araştırmada eğitsel oyun ve işbirlikli öğrenmenin 6. sınıf öğrencilerinin akademik başarıları, sosyal becerileri ve fen öğrenimi motivasyonları üzerindeki etkilerini belirlemek amaçlanmıştır. Araştırmada öntest-sontest karşılaştırma gruplu yarı deneysel desen kullanılmıştır. Araştırmanın çalışma grubunu, 2015-2016 akademik yılında Ağrı il merkezindeki bir ortaokulun altıncı sınıfına devam eden 52 öğrenci oluşturmaktadır. Veri toplama aracı olarak; Akademik Başarı Testi, Sosyal Beceri Ölçeği ve Fen Öğrenimi Motivasyon Ölçeği kullanılmıştır. Veriler testin ve ölçeklerin hem uygulama başlangıcında hem de uygulama bitiminde uygulanarak elde edilmiştir. Veriler parametrik testlerin varsayımlarını sağladığı için analizlerde bağımsız gruplar t-testi kullanılmıştır. Uygulama sonunda eğitsel oyun ve işbirlikli öğrenmenin öğrencilerin akademik başarıları üzerinde benzer bir etkiye sahip olduğu belirlenmiştir. Öğrencilerin sosyal becerilerini ve motivasyonlarını geliştirmede eğitsel oyun yönteminin daha etkili olduğu bulunmuştur.

\section{A B S T R A C T}

The purpose of this research is to find out the effect of teaching "Electrical Conduction" subject, which is covered in the 6th grade Science course, through the educational game and cooperative experiment methods on students' academic achievements, social skills, and learning motivation levels. Pretest-posttest comparison group quasi-experimental design, which is an experimental research model, was used. The study group consists of 52 students studying at a secondary school in the city center of Ağrı in the 2015-2016 academic year. The data were collected via Academic Achievement Test, Social Skills Scale, and Students' Motivation toward Science Learning Scale. Independent groups t-test was used in analyzes. It was determined that educational game and cooperative experiment methods are effective at same level on students' academic achievements at the end of research. It was found that educational game method is more effective on developing students' social skills and science learning motivations.

\section{Giriş}

Toplumların gelecekte varlıklarını koruyabilmesi bilim ve teknoloji alanında ilerlemelerine ve gelişmelerine bağlıdır. $\mathrm{Bu}$ bağlamda eleştirel düşünme yeteneğine sahip, araştıran, sorgulayan, problem çözebilen ve üreten bireylerin yetiştirilmesi bir gerekliliktir. Bu bireylerin yetiştirilmesine duyulan ihtiyaç göz önüne alındığında fen derslerinin önemi bir kez daha anlaşılmaktadır (Kuşakçı-Ekim, 2007). Fen derslerinin önemini kavrayan toplumlar fen derslerinin

\footnotetext{
* Sorumlu yazar/Corresponding author.

e-posta: emre.yildiz@atauni.edu.tr
} 
etkililiğini artırmak amacıyla müfredatlarında iyileştirmeler ve düzenlemeler yapmaktadır (Çepni, 2011; Gençer ve Karamustafaoğlu, 2014). Müfredatta yapılan değişiklikler incelendiğinde daha çok öğrencileri derste tamamıla aktif kılmaya yönelik yeni yöntem ve tekniklere yer verildiği görülmektedir (Harris, Marcus, McLaren ve Fey, 2001; National Academy of Sciences, 2006).

Aktif öğrenme stratejisi kapsamında uygulanan yöntem ve teknikler fen bilimleri dersinde ihtiyaç duyulan etkili öğrenmeler için gerekli olan etkin öğrenme ortamını sağlamaktadır. Aktif öğrenme stratejisinin sınıf ortamında uygulanması dersleri daha zevkli ve ilgi çekici hale getirmekte, öğrenmeyi kolaylaştırmakta, anlamlı ve kalıcı öğrenmeler gerçekleştirmekte, öğretimde öğrencilere kazandırılması hedeflenen temel becerileri kazandırmakta, öğrencilerin bütünsel gelişimine katkıda bulunmaktadır (National Academy of Sciences, 2006; Saracaloğlu ve Aldan-Karademir, 2009; Uzuntiryaki, Çakır ve Geban, 2001).

Yetişkinler tarafindan genellikle boş zaman faaliyeti olarak nitelendirilen oyunlar anlaşılır, basit, ilgi çekici, eğlenceli bir biçimde farklı yetenek ve becerilere sahip tüm öğrencilerin aktif katılabileceği öğretim etkinliği olarak tasarlandığında aktif öğrenme yöntemlerinden biri olan eğitsel oyun yöntemi şeklinde ele alınabilmektedir (Adıüzel, 2010; Demirel, 1999; Kaya ve Elgün, 2015; Mangır, 1993). Eğitsel oyun yöntemi, kurallı ya da kuralsız gerçekleştirilebilen öğrencilerin bilişsel, duyuşsal, psikomotor, sosyal ve fiziksel yönlerden gelişimlerini destekleyen, maddi çıkar sağlamaya yönelik olmadan öğrencilerin severek ve isteyerek sürece dahil oldukları bir aktif öğrenme yöntemidir (Dönmez, 1999; Hazar, 2005). Eğitsel oyun yöntemi, öğrencilerin hayal gücü, yaratıcılık, eleştirel ve mantıksal düşünme, problem çözme, iletişim ve üst düzey zihinsel becerilerini geliştiren, eğlenceli, ilgi çekici ve zevkli yönleriyle öğrencilerin dikkatini çeken, kalıcı ve anlamlı öğrenmeler gerçekleştirmelerini sağlayan etkili bir yöntemdir (Kaptan ve Korkmaz, 1999; Kaya ve Elgün, 2015).

Eğitsel oyun yöntemi renkli, eğlenceli, zevkli, ilgi çekici uygulamaları ile öğrencilerin motivasyon düzeylerini, okula ve derse karşı tutumlarını olumlu yönde artırır (Bayırtepe ve Tüzün, 2007; Önen, Demir ve Şahin, 2012). Öğrenciler birlikte çalışma, yardımlaşma, paylaşma, arkadaşlık ve dostluk ilişkileri kurma, farklı düşüncelere sahip bireylerin düşüncelerine saygı gösterme, onları anlamaya çalışma, bireysel farklılıkları hoș görme, kurallara uyma, kişisel hak ve özgürlükleri koruma vb. birçok sosyal beceriyi oyunlar sırasında kazanmaktadır (Coşkun, Akarsu ve Karaiper, 2012; Karamustafaoğlu ve Kaya, 2013). Oyunlar; öğrencilerin iletişim becerilerini geliştirmesi, düşüncelerini farklı düşünce sistemlerine sahip insanları kırmadan, incitmeden, aşağılamadan ve zarar vermeden ifade etmeyi öğretmesi, özgüvenlerini artırması, insanlarla çıkar ilişkisi olmadan içten ve samimi ilişkiler kurmasına yardımcı olması gibi etmenler nedeniyle kişisel gelişim açısından vazgeçilmez uygulamalardır (Karamustafaoğlu ve Kaya, 2013; Şaşmaz-Ören ve Erduran-Avcı, 2004).

Ortaokul 6. sınıf öğrencilerinin, gelişim dönem özellikleri göz önüne alındığında, somut düşünmenin ön planda olduğu bir somut işlemler evresinden soyut işlemlere geçiş evresinde olduklarından dolayı ezbere yönelmeden ilgi çekici, eğlenceli ve zevkli bir öğrenme ortamında öğrenmelerin anlamlı ve kalıcı olmasını sağlamak için yaparak yaşayarak öğrenmenin üst düzeyde gerçekleştiği eğitsel oyun yönteminin kullanılması faydalı olacaktır (Gençer ve Karamustafaoğlu, 2014; Koçyiğit, Tuğluk ve Kök, 2007).

Öğrencilerin akademik gelişimlerini sağlamanın yanında eleştirel düşünme, iletişim ve problem çözme becerilerini geliştiren, motivasyonlarını artıran, derse, öğretmene ve okula karşı olumlu tutum kazanmalarını sağlayan bir diğer kabul görmüş model ise birçok yöntem ve tekniği ile işbirlikli öğrenme modelidir (Christison, 1990; Cooper, Prescott, Smith, Mueck ve Cuseo, 1984; Leikin ve Zaslavsky, 1997; Siegel, 2005; Webb, Sydney ve Farivor, 2002). İşbirlikli öğrenme, öğrencilerin ortak bir amacı gerçekleştirmek için küçük gruplar halinde sınıf içinde ve dışında çalıştıkları, her birinin öğrenme sürecine aktif biçimde katıldıkları, birbirlerinin öğrenmelerinden sorumlu oldukları, akademik, sosyal ve psikolojik gelişimlerini sağlayan bir öğrenme yaklaşımıdır (Şimşek, 2007).

1960'ların ortalarında Johnson ve Johnson tarafindan geliştirilen birlikte öğrenme tekniği işbirlikli öğrenme modelinde yer alan tekniklerden biridir. $\mathrm{Bu}$ teknikte bireysel ve grup olarak yarışmalar söz konusu değildir. Öğrenciler arası iş bölümü ve grupların ödüllendirilmesi ön plandadır ve öğrenciler tek bir ürün ortaya koymak için grupça çalışırlar, düşüncelerini ve materyallerini paylaşırlar ve grup amacını gerçekleştirmek için birbirlerine yardımcı olurlar. Tekniğin ilk aşamasında öğretmen akademik hedefleri ve iş birliği becerilerinin planlamasını yapar. Öğretilecek konunun kapsamı, sınıfin durumu, öğretim materyalleri ve zaman unsurları dikkate alınarak öğrenciler iki ile altı kişiden oluşan gruplara ayrılır. Gruplar oluşturulurken öğrencilerin akademik başarı, cinsiyet, yetenek, sosyoekonomik yapı gibi unsurlar dikkate alınarak heterojen olmasına özen gösterilir. Grupların rahat çalışabilecekleri ortamı sağlamak amacıyla sınıf düzeni uygun hale getirilir. Öğrencilerin her birinin sürece katılması için öğrenme materyallerinin veya öğrenilecek bilginin grup üyeleri arasında paylaştırılarak verilmesi gerekmektedir. Öğrenciler arasında grup bağlılığını oluşturmak amacıyla grup içi rol paylaşımı yapılabilir. Öğrencilerin ne yapmaları gerektiği ve nasıl yapacakları açıklanmalıdır. Tüm grup üyelerinin katkısını sağlamak için bireysel değerlendirmeler yapılır. Grup çalışmaları sırasında öğretmen grupları gözlemler ve gerektiği durumlarda müdahale eder. Gruplara açıklamalar yaparak, soruları cevaplayarak, tartışmalar gerçekleştirerek yardımcı olur. Birlikte çalışma konusunda sorun yaşayan gruplarda öğretmenin araya girerek iş birliğini sağlaması yararlı olabilir. Süreç sonunda öğrenciler öğrendiklerini kısaca özetleyebilmeli ve öğrendiklerini ne şekilde kullanacaklarını açıklayabilmelidir. Grup ürünleri, öğrenme çıktıları, grup çalışmalarının etkililiği ve bireysel ilerleme ölçülerek tüm sürecin değerlendirmesi yapılarak işlemler tamamlanır (Johnson, Johnson ve Stanne 2000; Kagan ve Kagan 2009; Şimşek, 2007).

Bu araştırmada da "Elektriğin İletimi" ünitesinde var olan kavram yanılgıları, ünitenin öğretiminde yaşanan sıkıntılar, öğrenciler tarafindan zor anlaşılması, soyut bir içeriğe sahip olması ve ilgi duyulmaması nedenleriyle (Abuzer, Gönen ve Yilmaz, 2005; Chambers ve Andre, 1997; Cohon, Eylon 
ve Ganiel, 1983; Demirci ve Çirkinoğlu, 2004; Eryılmaz ve Sencar, 2002; Geban, Ertenpınar ve Sönmez, 2002; Hardal ve Eryılmaz, 2002) bu ünitenin öğretiminde yukarıda bahsedilen faydalarından dolayı eğitsel oyun ve işbirlikli öğrenmenin etkileri kıyaslanmaya çalışılmıştır.

Alan yazın incelendiğinde eğitsel oyun araştırmalarında çoğunlukla dijital oyunların kullanıldığı (Aymen-Peker, 2018; Barringer, Plummer, Clerkin ve Gilligan, 2018; Dong, 2018; Espinoza-Morales, 2017; Harvey, 2018; Hung, Yang, Hwang, Chu ve Wang, 2018; Koka, 2018; Kregenow ve Palma, 2018; Martin, 2012; Mezei, 2015; Perkins, 2016; Stewart, 2013; Tsai ve Tsai, 2018), tek grup üzerinde etkisinin incelendiği (Bressler, 2014; Martin, 2012; Martinez-Hernandez, 2010; Shapiro, 2016) veya geleneksel öğretimle kıyaslandığı (Dumlu-Güler, 2011; Fırat, 2011; Gülsoy, 2013; Yeşilkaya, 2013), geleneksel öğretimi tamamlayan bir araç olarak kullanıldığı (Kaya ve Elgün, 2015; Neimeyer, 2006), başarı (Abdul-Jabbar ve Felicia, 2015; Alıc1, 2016; Clark ve Killingsworth, 2016; Eltem, 2018; Gençer, 2017; Gürpınar, 2017; Koka, 2018; Little, 2015; Nunes, Soares ve Catarino, 2018; Rouse, 2013) ve oyun içi (akış) motivasyonunun (Baisa, 2009; Bressler, 2014; Toprac, 2008; Zheng, 2012) araştırıldığ1 görülmektedir. İşbirlikli öğrenme modeli ile ilgili yapılan araştırmalarda genellikle işbirlikli öğrenme yöntem ve tekniklerinin geleneksel öğretimle (Ağgül, 2016; Arslan 2016; Firat, 2014; Tortumluoğlu, 2014) veya kendi aralarında kıyaslandığı (Çavdar, 2016; İyi, 2018; Kibirige ve Lehong, 2016; Koç, 2014; Öztürk, 2017; Yılar, 2015), başarı (Alghamdi, 2017; Avci, 2018; Genç, 2016; Fabian, Topping ve Barron, 2018; Göktaş, 2017; McCall, 2017; Rabgay, 2018; Turgut ve Turgut, 2018; Wyman, 2018) ve tutum (Alghamdi, 2017; Arslan, 2016; Avc1, 2015; Fabian, Topping ve Barron, 2018; Göktaş, 2017; Rabgay, 2018) gibi değişkenlerin incelendiği görülmektedir. $\mathrm{Bu}$ araştırmada alan yazındaki araştırmalardan farklı olarak gerçek ortamlarda oynanan oyunlar kullanılmış, fen öğreniminde en fazla kullanılan araçlardan olan deneyler öğrencilere işbirlikli öğrenme gruplarında bizzat yaptırılmış, yöntemlerin etkisi genellikle incelenen akademik başarı ve motivasyonun haricinde sosyal beceri üzerinde de incelenmeye çalışılmıştır.

$\mathrm{Bu}$ araștırmada 6. sınıf "Elektriğin İletimi" ünitesinde uygulanan eğitsel oyun ve işbirlikli öğrenmenin öğrencilerin akademik başarıları, sosyal becerileri ve fen motivasyonları üzerindeki etkilerini karşılaştırmak amaçlanmıștır. Araștırmanın problem cümlesi: "6. sınıf "Elektriğin İletimi" ünitesinde uygulanan eğitsel oyun ve işbirlikli öğrenmenin öğrencilerin akademik başarıları, sosyal becerileri ve fen motivasyonları üzerindeki etkisi nedir?" şeklinde belirlenmiştir. Bu kapsamda aşağıda yer alan araştırma sorularına cevap aranmıştır:

1. Eğitsel oyun ve işbirlikli öğrenme uygulanan öğrencilerin akademik başarıları arasında istatistiksel olarak anlamlı bir farklılık var mıdır?

2. Eğitsel oyun ve işbirlikli öğrenme uygulanan öğrencilerin sosyal becerileri arasında istatistiksel olarak anlamlı bir farklılık var mıdır?

3. Eğitsel oyun ve işbirlikli öğrenme uygulanan ögrencilerin fen motivasyonları arasında istatistiksel olarak anlamlı bir farklılık var mıdır?

\section{Yöntem}

$\mathrm{Bu}$ bölümde araştırma modeli, çalışma grubu, ver, toplama araçları, verilerin toplanması, verilerin analizi ve uygulama başlıkları yer almaktadır.

\subsection{Araștırma Modeli}

$\mathrm{Bu}$ araştırmada deneysel desenlerden öntest sontest karşılaştırma gruplu yarı deneysel desen benimsenmiştir. Yarı deneysel desenler araştırmaya dahil edilen bireylerin gruplara seçkisiz olarak atanmadığı ve tüm değişkenlerin kontrol altına alınamadığı deneysel desenlerdir. (McMillan ve Schumacher, 2006). Eğitimde yapılan araştırmalarda bağımlı değişken üzerinde etkisi olan tüm değişkenler kontrol altına alınamadığından dolayı ve çalışma grubundaki öğrencilerin deney gruplarına seçkisiz atamasının mümkün olmamasından dolayı araştırmanın amacına en çok uygun düşen yöntemdir. Bu araştırmada eğitsel oyun ve işbirlikli öğrenmenin öğrencilerin akademik başarıları, sosyal becerileri ve motivasyonları üzerindeki etkileri incelendiğinden bu desen tercih edilmiştir.

\section{2. Çalıșma Grubu}

$\mathrm{Bu}$ araştırma 2015-2016 akademik y1lı ikinci döneminde Ağrı il merkezindeki MEB'e bağlı bir ortaokulda gerçekleştirilmiştir. Çalışma grubunun seçilmesinde uygun örnekleme yöntemi benimsenmiştir. Uygun örnekleme yöntemi, çeşitli durumlar (işgücü, para, zaman, uygulama kolaylığı vb.) nedeniyle kolay ulaşılabilir ve uygulama yapilabilir birimlerden bireylerin örenekleme seçilmesidir (Büyüköztürk, Kılıç Çakmak, Akgün, Karadeniz ve Demirel, 2010).

Araştırmanın çalışma grubu 6. sınıfa devam eden 52 öğrenciden oluşmaktadır. Araştırmanın gerçekleştirildiği okulda yer alan 4 şube arasında kura çekilerek deney grupları belirlenmiştir. 24 öğrenci eğitsel oyun yönteminin uygulandığı Deney Grubu-1'de ve $28^{\prime} i$ işbirlikli öğrenmenin uygulandığı Deney Grubu-2'de yer almaktadır. Deney Grubu-1'de 11 erkek ve 13 kız öğrenci ve Deney Grubu-2'de ise 12 erkek ve 16 kız öğrenci bulunmaktadır.

\subsection{Veri Toplama Araçları}

Araştırmada; öğrencilerin akademik başarılarındaki değişimi karşılaştırmak için ABT, sosyal beceri düzeylerindeki değişimi belirlemek amacıyla SBÖ, fen öğrenimine yönelik motivasyonlarındaki değişimi tespit etmek için FMÖ kullanılmıştır.

\subsubsection{Akademik Başarı Testi (ABT)}

Öğrencilerin "Elektriğin İletimi” ünitesine yönelik önbilgi düzeylerini ve akademik başarılarındaki gelişimi tespit etmek amacıyla kullanılan Akademik Başarı Testi araştırmacılar tarafindan geliştirilmiştir. Testin kapsam geçerliğini sağlayabilmek açısından öncelikli olarak belirtke tablosu hazırlanmış ve ünitenin tüm kazanımları ile ilgili çoktan seçmeli sorular oluşturulmuştur. Taslak hali 30 maddeden oluşan test iki ayrı fen bilgisi eğitimi alan uzmanının görüşüne sunulmuştur. Uzmanlar başta soruların anlaşılırlıkları, öğrenci seviyesine uygunluğu vb. birçok açıdan incelemiştir. $\mathrm{Bu}$ sayede testin yapı geçerliği sağlanmaya çalışılmıştır. Uzmanlar incelemeleri neticesinde 
soruların kapsam geçerliğini tam olarak sağladığı, testin tek bir özelliği ölçmeye yönelik sorulardan oluştuğu ve yalnızca biçimsel düzenlemelere ihtiyaç duyulduğu belirlenmiştir. Uzman görüşleri doğrultusunda test maddeleri yeniden düzenlenerek üniteyi önceden öğrenmiş olan 97 kişilik bir gruba uygulanmıştır. Madde güçlük indeksi ve ayırt edicilik indeksi göz önüne alınarak çok zor, çok kolay ve ayırt ediciliği düşük olan beş madde testten atılmıştır ve son durumda test 25 maddeden oluşmaktadır. KR-20 güvenirlik katsayısı 0,82 olarak bulunmuştur. Testte doğru cevap verilen maddeler dört puan, yanlış cevaplanan ve boş bırakılan maddeler ise sıfir puan verilerek puanlandırılmıştır. Testten alınabilecek minimum puan sıfır ve maksimum puan 100'dür.

\subsubsection{Sosyal Beceri Ölçeği (SBÖ)}

Sosyal Beceri Ölçeği, öğrencilerin bazı temel sosyal beceri davranışlarını ölçmek amacıyla Kocayörük (2000), tarafindan geliştirilmiştir. 4'lü likert tipindeki ölçek 20 maddeden oluşmaktadır. Ölçeğin kapsam ve yapı geçerliliği çalışmalarında beş uzmandan görüş alınmış, ölçeğin istenen sosyal beceri davranışlarını ölçtüğü görülmüştür. Merhabaiyi günler dileme, kendini tanıtma, başkalarını tanıtma, konuşmayı başlatma, konuşmayı sürdürme, dinleme, soru sorma, teşekkür etme, göz teması kurma, izin isteme, yardım isteme, gruba katılma, iltifat etme, özür dileme, ikna etme, grup sorumluluğunu yerine getirme, iş bölümü ve kendini ödüllendirme gibi sosyal beceri davranışlarını ölçmektedir. Cronbach Alpha iç tutarlılık katsayısı 0,75 olarak bulunmuştur. Ölçeğin bu araştırma için Cronbach Alpha iç tutarlılık katsayısı 0,72 olarak hesaplanmıştır. Ölçekten alınabilecek maksimum puan 80 'dir ve minimum puan 20'dir.

\subsection{3. Öğrencilerin Fen Öğrenimi Motivasyon Ölçeği (FMÖ)}

Araştırmada fen dersine yönelik motivasyonlarını ölçmeyi amaçlayan, Yılmaz ve Çavaş (2007) tarafindan Türkçeye uyarlanan ölçek kullanılmıştır. Ölçek, fen öğrenmenin değeri, öğrenme ortamındaki özendiricilik, aktif öğrenme stratejileri, performans amacı, özyeterlik ve başarı amacı olmak üzere altı faktörden oluşmaktadır (Tuan, Chin ve Shieh, 2005). Ölçeğin güvenirliği Eşdeğer Yarılama ve Cronbach Alpha İç Tutarlık olmak üzere iki yöntemle hesaplanmış ve eşdeğer yarılama yöntemiyle elde edilen güvenirlik katsayısı da 0,89 , Cronbach Alpha güvenirlik katsayısı 0,87 olarak bulunmuştur. Ölçeğin geçerliğini sağlamak amacıyla yabancı dil, ölçme-değerlendirme ve fen eğitimi uzmanlarına başvurulmuştur. Ölçek 6., 7. ve 8 . sınıfta öğrenim gören öğrencilere uygulanmış ve ölçeğin geçerliği faktör analizi, madde toplam korelasyonları ve eşzaman ölçek geçerliği yöntemleri ile sağlanmıştır. Ölçeğin bu araştırma için güvenirlik katsayısı 0,84 olarak bulunmuştur. Ölçekten alınabilecek minimum puan 33 ve maksimum puan 165 'tir.

\subsection{Verilerin Toplanmas 1}

11.05.2020 tarihli ve 56785782-050.02.04-E.2000120947 sayılı Atatürk Üniversitesi Sosyal ve Beşeri Bilimler Etik Kurul Uygunluk-onay belgesine göre bu araştırmanın gerçekleştirilmesinde bilim etiğine aykırı bir durum yoktur.
2015-2016 akademik yılı ikinci yarısında gerçekleştirilen araştırmada benzer özelliklere sahip öğrencilerden oluşan iki deney grubu ile çalışılmıştır. Araştırma süreci deney gruplarındaki öğrencilere öntest olarak Akademik Başarı Testi (ABT-ön), Sosyal Beceri Ölçeği (SBÖ-ön) ve Fen Öğrenimi Motivasyon Ölçeği (FMÖ-ön) uygulanarak başlamıştır. Öntestlerin uygulanmasının ardından Deney Grubu-1 olarak seçilen gruba eğitsel oyun yöntemi uygulanmış ve Deney Grubu-2 olarak seçilen gruba ise işbirlikli öğrenme uygulanmıştır. Araştırma sontest olarak başlangıçta uygulanan Akademik Başarı Testi (ABT-son), Sosyal Beceri Ölçeği (SBÖ-son) ve Fen Öğrenimi Motivasyon Ölçeği (FMÖ-son) uygulanarak sonlandırılmıştır. Araştırmanın deneysel deseni Şekil-1'de verilmiştir.



Şekil 1. Araştırmanın Deneysel Deseni

Uygulama her iki deney grubunda da 16 ders saati (haftalık ardışık 2+2 saatlik ders) boyunca araştırmacılar tarafindan devam ettirilmiştir. Öntest ve sontestlerin uygulanma süreleri ile toplam uygulama süresi 22 saat olmuştur. Uygulamada "Elektriğin İletimi”" ünitesi eğitsel oyun ve işbirlikli öğrenme kullanılarak öğrencilere sunulmuştur. Uygulama sürecinde Şekil 2'de verilen kazanımlar çalışıllmıştır.

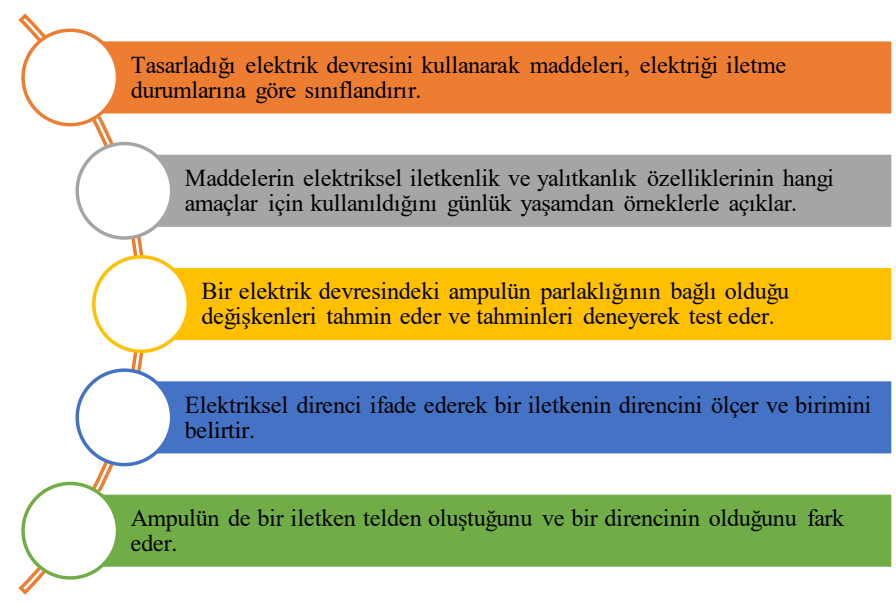

Şekil 2. "Elektriğin İletimi” Ünitesinin Kazanımları (MEB, 2013)

\subsubsection{Eğitsel Oyun Yönteminin Uygulanışı}

Deney Grubu-1 olarak seçilen grupta dersler eğitsel oyun yöntemi ile yürütülmüştür. $\mathrm{Bu}$ yöntemde Yıldız (2019) tarafindan geliştirilen eğitsel oyunlar kullanılmıştır. Uygulamanın başlangıcında öğrencilere eğitsel oyun yöntemi tanıtılmıştır. Her oyunun başlangıcında oyun kuralları öğrencilere açıklanmış ve örnek oyun uygulaması gerçekleştirilmiştir. Kavram öğretimine yönelik oyunlar araştırmacılar rehberliğinde bir tur oynatılmış ve ilk turun 
bitiminde öğrencilerin oyunda asıl dikkat etmeleri gereken noktalar, öğrenmeleri gereken bilgiler vurgulanmıştır. Daha sonra oyunun uzunluğuna göre bazı oyunlar ikinci kez, bazıları ise üçüncü kez oynatılmıştır. Kavram oyunlarının tamamlanmasının ardından değerlendirme tarzındaki oyunlar oynatılmıştır. Bu sayede kavram öğretimi oyunları ile kavramların öğretiminin ne derece etkili olduğu tespit edilmeye çalışılmıştır.

MEB ünitenin ilk iki kazanımı için altı ders saati önerdiğinden bu süre içerisinde iletken ve yalıtkan kavramlarının öğretimi için tasarlanan oyunlar oynatılmıştır. İlk iki saat kavram öğretimi amacıyla tasarlanan Kulaktan Kulağa Eğitsel Oyunu, sonraki iki saat kavram öğretimi ve pekiştirme amacıyla tasarlanan Sıra Sende Eğitsel Oyunu, bir ders saati değerlendirme amaciyla tasarlanan Deve-Cüce Eğitsel Oyunu ve son bir ders saati de değerlendirme ve yeni durumlara uyarlamayı öğretmek amacıyla tasarlanan Körebe Eğitsel Oyunu oynatılmıştır.

MEB ünitenin son üç kazanımı için 10 ders saati önerdiğinden dolayı bu kısımda ampul parlaklığına etki eden değişkenler, elektriksel direnç, ampulün de bir iletkenden oluştuğu ve direncinin olduğuna yönelik kazanımlar ele alınmıştır. İlk olarak iki ders saati süresince devre elemanlarının tanımları, özellikleri, şekilleri, devredeki gösterimleri, birimleri, sembolleri ve iletkenin direncinin bağlı olduğu durumların öğretilmesi amacıyla Kart-Kazan Eğitsel Oyunu oynatılmıştır. Öğrencilerin basit elektrik devresini kurmayı öğrenmeleri amacıyla tasarlanan Fen-Basket Eğitsel Oyunu iki ders saati süresince oynatılmıştır. iki ders saati süresince Yıldız Yağmuru Eğitsel Oyunu direncin bağlı olduğu durumların öğretilmesi amacıyla oynatılmıştır. Lambaların da dirençlerden oluştuğunu ve farklı dirençlerle kurulan devrelerdeki lamba parlaklığının nasıl değişeceğini öğretmek amacıyla iki ders saati süresince Par-Sön Eğitsel Oyunu oynatılmıştır. Son iki ders saati süresince öğretilen bilgilerin değerlendirilmesi amacıyla tasarlanan Bil-Kazan Eğitsel Oyunu oynatılarak uygulama süreci sonlandırılmıştır.

\subsection{2. İşbirlikli Öğrenmenin Uygulanması}

Deney Grubu-2 olarak seçilen grupta işbirlikli öğrenme uygulanmıştır. Ünitenin kazanımlarıyla ilgili hazırlanan dokuz deney işbirlikli öğrenme modelinde yer alan birlikte öğrenme tekniğine uygun şekilde gerçekleştirilmiştir. Öncelikli olarak öğrenciler akademik başarı ve cinsiyet değişkenleri göz önüne alınarak dörder kişilik yedi gruba ayrılmıştır. Gruplamada grup içi heterojen ve gruplar arası homojen yapı oluşturulmasına dikkat edilmiştir. Her grupta başarılı, orta düzey başarılı ve başarısız öğrenciler, kız ve erkek öğrenciler karışık olarak yer almıştır. Buradaki temel amaç farklı özelliklere sahip öğrencilerin bir araya getirilerek akademik, sosyal anlamda daha fazla gelişmelerini desteklemek, farklılıklara karşı hoşgörü ve saygı gibi davranışları desteklemektir. Başarılı öğrenciler başarısız arkadaşlarının akademik gelişimlerine yardımcı olurken başarısız öğrencilerin de belli ölçüde başarı gösteremezse grupça başarısız sayılacaklarının farkında oldukları bir süreçtir. Dolayısıyla öğrencilerde aidiyet, yardımlaşma, arkadaşlık ve birlik olma bilincinin de oluşumu desteklenmektedir. Gruplardaki öğrenciler birbirinden farklı özelliklere sahip bireylerden oluşurken gruplar arasındaki dengeyi sağlamak adına grupların birbirine denk olmasına özen gösterilmiştir. Sınıf düzeni birlikte öğrenme tekniğinin uygulanabileceği hale getirilmiş, işbirlikli öğrenme hakkında açıklama yapılmış ve yapılacak deneylerde öğrencilerin güvenliğini sağlamak amaciyla temel güvenlik önlemleri öğretilmiştir. Grup üyeleri bir araya gelerek gruplarını temsil edecek bir isim belirlemişler ve takım ruhunun oluşması için grup liderliği, malzemeci, araştırmacı ve yazıcı rollerinin paylaşımı sağlanmıştır. Bu roller dokuz deney sürecince gruptaki üyeler tarafindan dönüşümlü olarak üstlenilmiştir. Grup üyeleri her deneyde ilk olarak araştırmacılar tarafindan hazırlanan deney föylerinden grupça deneye çalışmıştır. Deney föyleri deneyin adı, kısa bir teorik bilgi, amacı, kullanılan malzemeler ve yapılışını içerecek şekilde hazırlanmış ve grup üyeleri arasında olumlu bağlılık sağlayacak şekilde her gruba birer adet temin edilmiştir. Aynı zamanda grup üyelerinin kendi kaynaklarını da getirmeleri istenmiştir. Araştırmacı rolündeki grup üyeleri arkadaşlarına ekstradan getirilen bu kaynaklardan deneyle ilgili daha derinlemesine bilgiler sunmuşlardır. Araştırmacılar gruplar arasında dolaşarak ek bilgiler vermiş, sorular sorarak grupların deney yapımına hazır olup olmadıklarını belirlemeye çalışmıştır. Gruplar deney yapmaya hazır oldukları zaman malzemeciler araştırmacıların sınıfa getirdikleri malzemelerin arasından yapılacak deneyle ilgili malzemeleri seçip gruplarına götürmüş̧ür. Grup üyeleri birlikte föyde verilen yönergeleri izleyerek deney düzeneklerini kurmuştur. Araştırmacılar kurulan deney düzeneklerini incelemiş ve uygun görüldüğünde düzenekler çalıştırılmıştır. Deneylerin tamamlanmasının ardından grup üyeleri bir araya gelmiş deney sonuçlarını tartışmışlardır. Bu esnada araştırmacılar gruplar arasında dolaşarak tartışmaları yönlendirmiş ve ek bilgiler vererek yanlış öğrenmelerin önüne geçmeye çalışmıştır. Tartışmaların tamamlanmasının ardından grup üyeleri birlikte grup deney raporlarını hazırlamıştır. Deney raporları araştırmacılar tarafından incelenerek her bir deneyin sonunda gruplara dönütler verilmiştir. İşbirlikli deney yöntemi kapsamında gerçekleştirilen deneyler Şekil 3 'te verilmiştir.



Şekil 3. İşbirlikli Deney Yöntemi Kapsamında Yapılan Deneyler 
İletken ve yalıtkan kavramları için "İletken Maddeler ve Yalıtkan Maddeler" deneyleri ikişer saat olmak üzere dört ders saatinde yapılmıştır. "Elektrikli Araçların İletken ve Yalıtkan Kısımları" deneyi iki ders saati süresince maddelerin elektriksel iletkenlik ve yalıtkanlık özelliklerinin öğretilmesi amacıyla gerçekleştirilmiştir. Elektrik devresindeki ampulün parlaklığının bağlı olduğu değişkenleri öğretmek için "Dirençleri Elektrik Devresine Bağlama, Elektriksel Direnç İletkenin Uzunluğuna Bağlı Mıdır?, Elektriksel Direnç İletkenin Kesit Alanına Bağlı Mıdır?, Elektriksel Direnç İletkenin Cinsine Bağlı Mıdır?" deneyleri altı ders saati süresinde yapılmıştır. Sonraki iki ders saatinde direnç kavramı ve direncin ölçülmesini öğretmek amacıyla "Direnç Ölçer Kullanarak Direncin Ölçülmesi” deneyi gerçeklştirilmiştir. Ünitenin son iki ders saatinde "Ampül Bir Dirençten Mi Oluşur?" deneyi lambaların da dirençlerden oluştuğunu öğretmek amacıyla yapılmıştır.

\subsection{Verilerin Analizi}

Uygulamadan elde edilen verilerin analizinden önce normallik dağılımları incelenmiş ve parametrik testlerin varsayımlarını sağlayıp sağlamadığı kontrol edilmiştir. Verilerin istatistiksel analizlerinde betimsel istatistik ve Bağımsız Örneklemler T-Testi kullanılmış ve Cohen Etki Büyüklüğü değerleri hesaplanmıştır. İstatistiksel analizlerde anlamlılık düzeyi 0.05 alınmıştır. Analizler SPSS 20 paket programı aracılığıyla gerçekleştirilmiştir.

\section{Bulgular}

$\mathrm{Bu}$ bölümde araştırmada elde edilen verilerin analiz sonuçlarına ait bilgiler sunulmuştur.

\subsection{Birinci Araştırma Sorusuna Ait Bulgular}

Uygulama başlangıcında öğrencilerin "Elektriğin İletimi" ünitesine ait önbilgi düzeylerini belirlemek amaciyla yapılan ABT-ön testine ait bağımsız gruplar t-testi sonuçları Tablo 1'de verilmiştir.

Tablo 1. ABT-ön'den Elde Edilen Verilerin Bağımsız Gruplar tTesti Sonuçları

\begin{tabular}{ccccccc}
\hline Grup & N & X & ss & df & t & p \\
\hline Deney Grubu-1 & 24 & 29,69 & 10,82 & & & \\
Deney Grubu-2 & 28 & 31,99 & 9,94 & 50 & $-0,797$ & 0,429 \\
\hline
\end{tabular}

Tablo 1'de verilen analiz sonuçlarına göre öğrencilerin uygulama başlangıcında "Elektriğin İletimi" ünitesine yönelik önbilgi düzeyleri arasında anlamlı bir farklılık olmadığı belirlenmiştir; $\left(\mathrm{t}_{(50)}=-0,797 ; \mathrm{p}>0,05\right)$. Öğrencilerin akademik başarıları üzerine yöntemlerin etkisini tespit etmek amaciyla uygulanan ABT-son testinden elde edilen verilerin bağımsız gruplar t-testi sonuçları Tablo 2'de verilmiştir.

Tablo 2. ABT-son'dan Elde Edilen Verilerin Bağımsız Gruplar tTesti Sonuçları

\begin{tabular}{ccccccc}
\hline Grup & $\mathrm{N}$ & $\mathrm{X}$ & $\mathrm{ss}$ & $\mathrm{df}$ & $\mathrm{t}$ & $\mathrm{p}$ \\
\hline Deney Grubu-1 & 24 & 71,18 & 18,23 & & & \\
Deney Grubu-2 & 28 & 73,74 & 16,68 & 50 & $-0,528$ & 0,600 \\
\hline
\end{tabular}

Tablo 2'de verilen analiz sonuçlarına göre eğitsel oyun ve işbirlikli öğrenmenin uygulandığı öğrencilerin akademik başarıları arasında anlamlı bir farklılığın olmadığı tespit edilmiştir; $\left(\mathrm{t}_{(50)}=-0,528 ; \mathrm{p}>0,05\right)$. Eğitsel oyun yöntemi uygulanan öğrencilerin akademik başarılarındaki değişimin anlamlı olup olmadığını tespit etmek amaciyla yapılan bağımlı gruplar t-testi analiz sonuçları Tablo 3'te verilmiştir.

Tablo 3. Eğitsel Oyun Yöntemine Ait Bağımlı Gruplar t-Testi Sonuçları

\begin{tabular}{rllllcl}
\hline Test & $\mathrm{N}$ & $\mathrm{X}$ & $\mathrm{ss}$ & $\mathrm{df}$ & $\mathrm{t}$ & $\mathrm{p}$ \\
\hline Öntest & 24 & 29,69 & 10,84 & 23 & $-11,048$ & 0,000 \\
Sontest & 24 & 71,18 & 18,23 & & & \\
\hline
\end{tabular}

Tablo 3'te verilen analiz sonuçlarına göre eğitsel oyun yönteminin öğrencilerin akademik başarılarını anlamlı düzeyde artırdığı tespit edilmiştir; $\left(\mathrm{t}_{(23)}=-11,048 ; \mathrm{p}<0,05\right.$; $\left.\eta^{2}=0,84\right)$. Öğrencilerin akademik başarılarında gözlemlenen varyansin \%84'ü uygulanan eğitsel oyun kaynaklanmaktadır. Cohen (1988)'e göre bu değer çok büyük etki olarak adlandırılmaktadır. İşbirlikli deney uygulaması yapılan öğrencilerin akademik başarılarındaki değişimin anlamlı olup olmadığını tespit etmek amacıyla yapılan bağımlı gruplar t-testi analiz sonuçları Tablo 4'te verilmiştir.

Tablo 4. İşbirlikli Deney Uygulamasına Ait Bă̆ımlı Gruplar tTesti Sonuçları

\begin{tabular}{rllllll}
\hline Test & $\mathrm{N}$ & $\mathrm{X}$ & $\mathrm{ss}$ & $\mathrm{df}$ & $\mathrm{t}$ & $\mathrm{p}$ \\
\hline Öntest & 28 & 31,99 & 9,94 & 27 & $-12,819$ & 0,000 \\
Sontest & 28 & 73,74 & 16,68 & & & \\
\hline
\end{tabular}

Tablo 4'te verilen analiz sonuçlarına göre işbirlikli öğrenme uygulamasının öğrencilerin akademik başarılarını anlamlı düzeyde artırdığı tespit edilmiştir; $\left(\mathrm{t}_{(27)}=-12,819 ; \mathrm{p}<0,05\right.$; $\left.\eta^{2}=0,86\right)$. Öğrencilerin akademik başarılarında gözlemlenen varyansınv \%86's1 uygulanan eğitsel oyun kaynaklanmaktadır. Cohen (1988)'e göre bu değer çok büyük etki olarak adlandırılmaktadır.

\section{2. İkinci Araştırma Sorusuna Ait Bulgular}

Öğrencilerin uygulama öncesindeki sosyal beceri düzeylerini belirlemek amaciyla uygulanan SBÖ-ön'den elde edilen verilerin analiz sonuçları Tablo 5 'te verilmiştir.

Tablo 5. SBÖ-ön'den Elde Edilen Verilerin Bağımsız Gruplar tTesti Sonuçları

\begin{tabular}{ccccccc}
\hline Grup & N & X & ss & df & t & p \\
\hline Deney Grubu-1 & 24 & 61,04 & 12,04 & & & \\
Deney Grubu-2 & 28 & 60,34 & 8,38 & 40,158 & 0,246 & 0,807 \\
\hline
\end{tabular}

Tablo 5'te verilen analiz sonuçlarından görüldüğü üzere uygulama başlangıcında öğrencilerin sosyal becerileri arasında anlamlı bir farklılık bulunmamaktadır; $\left(\mathrm{t}_{(40,158)}=0,246 ; \quad \mathrm{p}>0,05\right)$. Uygulama sonunda öğretim yöntemlerinin öğrencilerin sosyal becerileri üzerindeki etkisini belirlemek amaciyla uygulanan SBÖ-son'dan elde edilen verilerin bağımsız gruplar t-testi sonuçları Tablo 6'da verilmiştir. 
Tablo 6. SBÖ-son'dan Elde Edilen Verilerin Bağımsız Gruplar TTesti Sonuçları

\begin{tabular}{ccccccc}
\hline Grup & $\mathrm{N}$ & $\mathrm{X}$ & $\mathrm{ss}$ & $\mathrm{df}$ & $\mathrm{t}$ & $\mathrm{p}$ \\
\hline Deney Grubu-1 & 24 & 68,25 & 9,13 & & & \\
Deney Grubu-2 & 28 & 61,86 & 9,07 & 50 & 2,526 & 0,015 \\
\hline
\end{tabular}

Tablo 6'da verilen analiz sonuçlarına göre öğrencilerin sosyal beceri düzeyleri arasında eğitsel oyun yöntemi uygulanan öğrenciler lehine anlamlı farklılık olduğu belirlenmiştir; $\left(\mathrm{t}_{(50)}=2,526 ; \mathrm{p}<0,05 ; \eta^{2}=0,10\right)$. 0,10 olarak hesaplanan eta-kare etki büyüklüğü Cohen (1988) tarafindan orta etki olarak sinıflandırılmaktadır. Buna göre, öğrencilerin sosyal becerileri arasında gözlenen değişkenliğin \%10 oranında uygulanan öğretim yöntemlerinden kaynaklandığı söylenebilir.

\section{3. Üçüncü Araştırma Sorusuna Ait Bulgular}

Uygulama başlangıcında öğrencilerin fen öğrenimi motivasyon düzeylerini tespit etmek amaciyla uygulanan FMÖ-ön'den elde edilen verilerin bağımsız gruplar t-testi sonuçları Tablo 7'de verilmiştir.

Tablo 7. FMÖ-ön'den Elde Edilen Verilerin Bağımsız Gruplar TTesti Sonuçları

\begin{tabular}{ccccccc}
\hline Grup & $\mathrm{N}$ & $\mathrm{X}$ & $\mathrm{ss}$ & $\mathrm{df}$ & $\mathrm{t}$ & $\mathrm{p}$ \\
\hline Deney Grubu-1 & 24 & 116,71 & 25,63 & & & \\
Deney Grubu-2 & 28 & 110,93 & 25,74 & 50 & 0,809 & 0,422 \\
\hline
\end{tabular}

Tablo 7'de verilen analiz sonuçlarından görüldüğü üzere uygulama başlangıcında öğrencilerin fen öğrenimi motivasyonları arasında anlamlı bir farklılık bulunmamaktadır; $\left(\mathrm{t}_{(50)}=0,809 ; \mathrm{p}>0,05\right)$. Uygulama sonunda yöntemlerin öğrencilerin fen öğrenimi motivasyonları üzerindeki etkisini belirlemek amacıyla uygulanan FMÖson'dan elde edilen verilerin bağımsız gruplar t-testi sonuçları Tablo 8'de verilmiştir.

Tablo 8. FMÖ-son'dan Elde Edilen Verilerin Bağımsız Gruplar TTesti Sonuçları

\begin{tabular}{ccccccc}
\hline Grup & N & X & ss & df & t & p \\
\hline Deney Grubu-1 & 24 & 149,79 & 15,01 & & & \\
Deney Grubu-2 & 28 & 132,07 & 21,31 & 50 & 3,411 & 0,001 \\
\hline
\end{tabular}

Tablo 8'de verilen analiz sonuçları incelendiğinde öğrencilerin fen öğrenimi motivasyonları arasında eğitsel oyun yöntemi uygulanan öğrenciler lehine anlamlı farklılık olduğu görülmektedir; $\quad\left(\mathrm{t}_{(50)}=3,411 ; \mathrm{p}<0,05 ; \quad \eta 2=0,19\right)$. Hesaplanan 0,19 eta-kare etki büyüklüğü büyük etki olarak sınıflandırılmaktadır (Cohen, 1988). Buna göre öğrencilerin fen öğrenimi motivasyonlarında gözlemlenen değişkenliğin \%19 oranında uygulanan öğretim yöntemlerinden kaynaklandığı söylenebilir.

\section{Tartışma, Sonuç ve Öneriler}

Eğitsel oyun ve işbirlikli öğrenmenin öğrencilerin akademik başarıları üzerindeki etkilerinin kıyaslanmaya çalışıldığı bu araştırmanın sonucunda bu yöntemlerin öğrencilerin akademik başarılarını geliştirmede benzer düzeyde etkili olduğu ancak her iki yöntemin de öğrencilerin akademik başarılarını anlamlı derecede artırdığı bulunmuştur. Eğitsel oyun yöntemi, sağladığı eğlenceli ortam sayesinde öğrencilerin severek ve isteyerek dahil olduğu kendi deneyimleri aracılığıyla yaparak yaşayarak öğrendikleri ve somut bilgiler edindikleri bir aktif öğrenme sürecidir. Eğitsel oyunlar, öğrencilerin derse katılımını artıran, dikkat süresini uzatan, derse ve öğretmene olumlu tutum geliştirmeyi sağlayan, öğrenme eksikliklerini ortaya çıkarıp gideren, eleştirel düşünme, problem çözme, zamanı etkili ve verimli kullanma, iletişim, hoşgörü, sağlıklı düşünme, karar alma ve uygulama vb. becerileri geliştiren, bilişsel, duyuşsal ve psikomotor gelişimi artıran ilgi çekici ve merak uyandırıcı aktivitelerden oluşmaktadır (Akandere, 2012; Bilen, 2002; Pehlivan, 2014; Yıldız, 2019; Yıldız, Şimşek ve Ağdaş, 2018). İlgili alan yazında eğitsel oyun yönteminin (Abdul Jabbar ve Felicia, 2015; Anderson, 2008; Aymen-Peker, 2018; Can, 2017; Canbay, 2012; Clerkin ve Gilligan, 2018; Eltem, 2018; Koka, 2018; Little, 2015) geleneksel ve programa dayalı öğretime göre öğrencilerin akademik başarılarını geliştirmede etkili olduğu yapılan araştırmalarla ortaya konmuştur. İşbirlikli öğrenme modelinde ise öğrenciler pasif dinleyen birey rolünden sıyrılıp, aktif olarak çalışan, araştıran, sorgulayan, paylaşan, irdeleyen ve düşünen bireyler olarak bilgiyi kendileri yapılandırmakta ve özümsemektedir (Huang, Huang ve Yu, 2011; Slavin, 1992; Smith, Johnson ve Johnson, 1981; Webb 1980). Grup arkadaşları ile etkileşim halinde olan öğrenciler çalışma konusuyla ilgili olarak sürekli fikir alışverişi yapma, kendilerini ifade etme, farklı fikirlerle karşılaşma ve karşılaşılan problem durumuyla ilgili çözüm önerileri üretme gibi davranışlar sayesinde öğrencilerin problem çözme becerileri (Açıkgöz, 1992; Gillies, 2006; Hennessy ve Evans, 2006; Senemoğlu, 2005; Smith, Johnson ve Johnson, 1981), eleştirel ve yaratıcı düşünme becerileri (Şimşek, Şimşek ve Doymuş, 2006) gelişmektedir. İlgili alan yazında işbirlikli öğrenme modelindeki yöntem ve tekniklerin geleneksel ve programa dayalı öğretime göre öğrencilerin akademik başarılarını geliştirmede etkili olduğu belirtilmiştir (Ağgül, 2016; Avci, 2018; BarataAksoy, 2017; Fabian, Topping ve Barron, 2018; İyi, 2018; Kılıç, 2016; Kibirige ve Lehong, 2016; McCall, 2017; Mutlu-Bayraktar ve Camnalbur, 2018; Rabgay, 2018; Turgut ve Turgut, 2018). Bu araştırma sonucunda eğitsel oyun ve işbirlikli öğrenmenin öğrencilerin akademik başarıları üzerinde benzer etkiye sahip olduğu sonucuna ulaşılmıştır. Bu durumun alan yazında belirtildiği gibi her iki yöntemin de süreçte öğrencileri aktif kılması, yaparak yaşayarak öğrenmenin üst düzeyde gerçekleşmesi, öğrencilerin ilk elden somut deneyimlerle öğrenmelerini sağlaması nedenlerinden kaynaklandığı söylenebilir.

Alan yazında farklı özelliklere sahip bireylerin birlikte çalışmasının öğrencilerin farklılıklara saygı duyma, fikirlerini ifade etme, dinleme, tartışma, sorumluluk alma, dayanışma, aidiyet, yardımlaşma ve hoşgörü gibi birçok özellik açsısından gelişmesini sağladığı belirtilmektedir (Baghcheghi, Koohestani ve Rezaei, 2011; Ebrahim, 2012; Gallardo, Cirugeda ve Rubio, 2012; Goudas ve Magotsiou, 2009; Johnson ve Johnson, 1989; Kagan, 1994; Madden ve Slavin, 1983; Shekarey, 2012; Slavin, 1991; Şimşek, Şimşek ve Doymuş, 2006; Zentall, Kuester ve Craig, 2011). Ancak bu araştırmada öğrencilerin sosyal becerilerini geliştirmede eğitsel oyun yönteminin işbirlikli öğrenmeye göre daha etkili olduğu belirlenmiştir. Bu durumun nedeni olarak oyun sırasında çocuğun kendini tanıma, sınırlarını ve 
gizil güçlerini keşfetme, çevresinin olanaklarını fark etme ve uyum sağlama, kendini ifade etme, sosyal roller ve ilişkileri kendiliğinden doğal bir ortamda öğrenmelerinden kaynaklandığı söylenebilir (Piaget, 1962; Yıldız, Şimşek ve A ̆gdaş, 2017).

İlgili alan yazında işbirlikli öğrenmenin öğrencilerin motivasyonlarını artırdığını belirten birçok araştırma bulunmaktadır (Avc1, 2015; Eymur ve Geban, 2016; Ghufron ve Ermawati, 2018). Ancak işbirlikli öğrenme modeli eğitsel oyun yöntemi ile kıyaslandığında eğitsel oyun yönteminin motivasyonu artırmada daha etkili olduğu belirlenmiştir. Oyunların öğrenciler için hayatın bir parçası olması, stresten ve kaygıdan uzak bir öğrenme ortamı sağlaması, öğrenme ortamını zevkli, eğlenceli ve ilgi çekici hale getirmeleri, gibi etmenler bu durumun nedeni olarak gösterilebilir (Bayırtepe ve Tüzün, 2007; Clerkin ve Gilligan, 2018; Coşkun, Akarsu ve Karaiper, 2012; Karamustafaoğlu ve Kaya, 2013; Önen, Demir ve Şahin, 2012; Şaşmaz-Ören ve Erduran-Avc1, 2004). Bu araştırmadan elde edilen araştırma sonuçları alan yazında eğitsel oyunların öğrencilerin motivasyonlarını geliştirdiğini belirten araştırmaların sonuçları ile uyumludur (Baisa, 2009; Bressler, 2014; Nunes, Soares ve Catarino, 2018; Reynolds-Perez, 2017; Rouse, 2013; Say ve Bağ, 2017; Toprac, 2008; Yıldız, Şimşek ve Aras, 2016). Bu araştırmadan elde edilen sonuçlar eğitsel oyunların motivasyon üzerinde etkisinin olmadığını belirten AtwoodBlaine (2015) ile ters düşmektedir. Benzer şekilde 6. sınıf düzeyinde gerçekleştirilen ancak farklı bir sonuç ortaya koyan araştırmada bu araştırmadan farklı olarak dijital oyunlar kullanılması sonuçların farklılaşmasına neden olmuş olabilir.

2015-2016 akademik yılı， 6. sinıf düzeyi, "Elektriğin İletimi" ünitesi, 16 ders saati ve eğitsel oyun ve işbirlikli öğrenme ile sinırlı olan bu araştırma neticesinde eğitsel oyun yönteminin öğrenme motivasyonu ve sosyal becerileri geliştirmede daha etkili olduğu sonucundan yola çıkarak gelecekte yapılacak olan çalışmalar için bazı öneriler aşağıda verilmiştir:

- Motivasyonunun düşük olduğu sinıflarda eğitsel oyun yönteminin kullanılması öğrencilerin motivasyonlarını artırmada fayda sağlayabilir.

- Sosyal becerilerin zayıf olduğu sınıflarda eğitsel oyun yönteminin kullanılması fayda sağlayabilir.

- Eğitsel oyun yönteminin motivasyon ve sosyal beceri üzerindeki etkileri farklı aktif öğrenme yöntem ve teknikleri ile kıyaslanabilir.

- Benzer uygulamalar daha uzun sürelerde gerçekleştirilerek başarıya, sosyal becerilere ve motivasyona etkileri incelenebilir.

- Farklı ünitelerin öğretiminde bu yöntemlerin etkileri incelenebilir.

- Farklı sinıf düzeylerinde bu yöntemler uygulanarak etkileri inecelenebilir.

- Eğitsel oyun yönteminin uygulanması sırasında öğrencilere yöntemin tanıtımı mutlaka yapılmalı, oyun sırasında çıkacak tartışmaları önlemek adına mutlaka oyun kuralları oyun başında iyice öğretilmeli ve örnek oyun uygulaması yapılarak ögrenciler oyuna hazırlanmalıdır.
- Oyunda öğretilmek istenilen kavramların vurgulanması için ara değerlendirmeler yapılmalı ve kavramlar tekrar edilmelidir.

- Öğrencilerin oyunu kaybetme nedenleri hakkında dönütler hazırlanmalı, hangi kavramları doğru öğrenemedikleri için oyunu kaybettikleri hakkında bilgilendirme yapılmalıdır.

- İşbirlikli öğrenmenin olmazsa olmazları olumlu bağlılık, her durumda birlikte hareket etme, birlikte kazanma ya da kaybetme gibi unsurlar hakkında öğrenciler bilgilendirilmeli ve süreç boyunca işbirlikli öğrenme ruhuna zarar verebilecek durumların ortaya çıkmaması için süreç kontrol edilmelidir.

- İşbirlikli çalışmaya öğrencilerin hazırlanmasında grup isminin, rollerin ve dönüşümlü grup liderlerinin belirlenmesi oldukça faydalı olmaktadır. Ancak bu sürece tüm grup üyelerinin birlikte katılmaları herkesin fikrinin değerlendirilmesi ve sonuçta ortak bir karara varılması durumları dikkatli bir şekilde takip edilmelidir.

- Deneyler sırasında gerekli güvenlik önlemlerinin alınması öğrencilerin kendilerine veya bir başkasına zarar vermelerini önlemek adına önem arz etmektedir. $\mathrm{Bu}$ nedenle güvenlik önlemleri öğrencilere öğretilmeli ve bu önlemlerin uygulanması sıkı bir şekilde takip edilmelidir.

\section{Kaynakça}

Abdul-Jabbar, A. I. ve Felicia, P. (2015). Gameplay engagement and learning in game-based learning: A systematic review. Review of Educational Research, 85(4), 740-779. https://doi.org/10.3102/0034654315577210

Abuzer, A., Gönen, S. ve Y1lmaz, A. (2005). Fen bilgisi öğretmen adaylarının karışımların yapısı ve iletkenliği konusundaki kavram yanılgıları. Hacettepe Üniversitesi Ĕ̈itim Fakültesi Dergisi, 28, 1-8.

Açıkgöz, K. (1992). İşbirlikçi öğrenme kuram araştırma uygulama. Malatya: Uğurel Matbaası.

Adıgüzel, Ö. (2010). Eğitimde yaratıcı drama. Ankara: Naturel Yayınevi.

Ağgül, Ö. (2016). Bitki ve hayvanlarda üreme, büyüme ve gelişme ünitesinin ögretiminde okuma-yazmauygulama yönteminin öğrencilerin akademik başarlart, epistemolojik tutumları ve okuduğunu anlamaları üzerine etkisi (Yayımlanmamış yüksek lisans tezi). Atatürk Üniversitesi, Erzurum.

Akandere, M. (2012). Eğitici okul oyunlart. Ankara: Nobel Yayınlar1.

Alghamdi, A. (2017). Impact of jigsaw on the achievement and attitudes of Saudi Arabian male high school science students (Unpublished doctoral dissertation). University of Akron, USA.

Alıc, D. (2016). Fen ve teknoloji dersinde eğitsel oyunların ögrencilerin akademik başarısına ve bilginin 
kalıcılı̆̆ına etkisinin incelenmesi (Yayımlanmamış yüksek lisans tezi). Kahramanmaraş Sütçü İmam Üniversitesi, Kahramanmaraş.

Anderson, J. L. (2008). The kids got game: Computer/video games, gender and learning outcomes in science classrooms (Unpublished doctoral dissertation). Boston College, USA.

Arslan, A. (2016). İşbirlikli öğrenme modelinin fen ögretimi laboratuar uygulamalart dersinde akademik başarı, kalıcılık ve tutuma etkileri (Yayımlanmamış doktora tezi). Fırat Üniversitesi, Elazığ.

Atwood-Blaine, D. (2015). The effect of playing a science center-based mobile game: Affective outcomes and gender differences. (Yayımlanmamış doktora tezi). University of Kansas, USA.

Avcı, F. (2015). Maddenin yapısı ve özellikleri ünitesine yönelik işbirlikli ögrenmeye dayalı öğretim programının bilişsel ve duyuşsal alan değişkenlerine etkisi (Yayımlanmamış doktora tezi). İstanbul Üniversitesi, İstanbul.

Avci, M. (2018). 6. sinıffen bilimleri dersi "Vücudumuzda Sistemler" ünitesinin işbirlikli öğrenme modeliyle ögretiminin öğrenci başarısına etkisi (Yayımlanmamış yüksek lisans tezi). Fırat Üniversitesi, Elazı̆̆.

Aymen-Peker, E. (2018). 5. sinıf "Canlılar Dünyasın Gezelim ve Tantyalım" ünitesinin klasik eğitsel oyunlar ve teknoloji destekli eğitsel oyunlarla ögretiminin değerlendirilmesi (Yayımlanmamış doktora tezi). Ondokuz Mayıs Üniversitesi, Samsun..

Baghcheghi, N., Koohestani, H. R. ve Rezaei, K. (2011). A comparison of the cooperative learning and traditional learning methods in theory classes on nursing students' communication skill with patients at clinical settings. Nurse Education Today, 31(8), 877-882.

Baisa, R. D. (2009). The relationship of video game play to integrated scientific processing skills. (Yayımlanmamış doktora tezi). Northern Illinois University, USA

Barata-Aksoy, Ş. (2017). 7. sınıf fen ve teknoloji dersi "Insan ve Çevre" ünitesinin işbirlikli öğrenme modeliyle öğretiminin ögrenci başartsina etkisi (Elâzı̆̆ ili örneği) (Yayımlanmamış yüksek lisans tezi). Frrat Üniversitesi, Elazı̆̆.

Barringer, D. F., Plummer, J. D., Kregenow, J. ve Palma, C. (2018). Gamified approach to teaching introductory astronomy online. Physical Review Physics Education Research, 14(1), 1-13. doi. 10.1103/PhysRevPhysEducRes.14.010140

Bayırtepe, E. ve Tüzün, H. (2007). Oyun-Tabanlı öğrenme ortamlarının öğrencilerin bilgisayar dersindeki başarıları ve öz-yeterlik algıları üzerine etkileri. Hacettepe Üniversitesi Eğitim Fakültesi Dergisi, 33(33), 41-54.

Bilen, M. (2002). Plandan uygulamaya öğretim. Ankara: Anı Yayıncilık.
Bressler, D. M. (2014). Is it all in the game? flow experience and scientific practices during an INPLACE mobile game (Unpublished doctoral dissertation). Lehigh University, USA.

Büyüköztürk, Ş., K. Çakmak, E., Akgün, Ö. Erkan, Karadeniz, Ş. ve Demirel, F. (2010). Bilimsel araştırma yöntemleri. Ankara: Pegem A.

Can, S. (2017). Fen bilimleri dersi maddenin değişimi ünitesinde eğitsel oyunların kullanılmasının 5. sinıf ögrencilerinin akademik başarı ve derse karşı tutumuna etkisi. (Yayımlanmamış yüksek lisans tezi). Marmara Üniversitesi, İstanbul.

Canbay, İ. (2012). Matematikte eğitsel oyunların 7. sinıf ögrencilerinin özdüzenleyici ögrenme stratejileri, motivasyonel inançları ve akademik başarlarına etkisinin incelenmesi (Yayımlanmamış yüksek lisans tezi). Marmara Üniversitesi, İstanbul.

Chambers, S. K. ve Andre, T. (1997). Gender, prior knowledge, interest, and experience in electricity and conceptual change text manipulations in learning about direct current. Journal of Research in Science Teaching, 34, 107-123.

Christison, M.A. (1990). Cooperative learning in the EFL classroom. English Teaching Forum, 28, 6-9.

Clark, T. S. ve Killingsworth. S. S. (2016). Digital games, design, and learning: A systematic review and metaanalysis. Review of Educational Research, 86(1), 7922. https://doi.org/10.3102/0034654315582065

Clerkin, A. ve Gilligan, K. (2018). Pre-school numeracy play as a predictor of children's attitudes towards mathematics at age 10. Journal of Early Childhood Research, 16(3), 319-334. https://doi.org/10.1177/1476718X18762238

Cohen, J. (1988). Statistical power analysis for the behavioral sciences (2nd ed.). Hillsdale, NJ: Lawrence Earlbaum Associates.

Cohon, R., Eylon, B. ve Ganiel, U., (1983). Potential difference and current in simple electric circuits: a study of students' concepts. American Association of Physics Teachers, 51(5), 407-417.

Cooper, J., Prescott, S., Cook, L., Smith, L., Mueck, R. ve Cuseo, J. (1984). Cooperative learning and college instruction- effective use of student learning teams. California State University Foundation Publication, 41-65.

Coşkun, H., Akarsu, B. ve Karaiper, A. İ. (2012). Bilim öyküleri içeren eğitsel oyunların fen ve teknoloji dersindeki öğrencilerin akademik başarılarına etkisi. Ahi Evran Üniversitesi Kırşehir Eğitim Fakültesi Dergisi (KEFAD), 13(1), 93-109.

Çavdar, O. (2016). Fen ve teknoloji dersinin ögrretiminde iyi bir eğitim ortamı için yedi ilke ve modellerin işbirlikli ögrenme yöntemiyle uygulanması (Yayımlanmamış doktora tezi). Atatürk Üniversitesi, Erzurum.

Çepni S. (Ed.). (2011). Fen ve teknoloji öğretimi. (9. Baskı). Ankara: Pegem. 
Demirci, N. ve Çirkinoğlu, A. (2004). Öğrencilerin elektrik ve manyetizma konularında sahip oldukları ön bilgi ve kavram yanılgılarının belirlenmesi. Türk Fen Ĕgitimi Dergisi, 1(2), 116-138.

Demirel, Ö. (1999). Planlamadan değerlendirmeye öğretme sanatı. Ankara: Pegem A.

Dong, P. I. (2018). Exploring Korean parents' meanings of digital play for young children. Global Studies of Childhood, $\quad$ 8(3), 238-251. https://doi.org/10.1177/2043610618798931

Dönmez, N. B. (1999). Oyun kitabı. İstanbul: Esin.

Dumlu-Güler, T. (2011). 6. siniffen ve teknoloji dersindeki "Hücre ve Organelleri" konusunun eğitsel oyun yöntemiyle ögretilmesinin ögrencilerin akademik başarısına etkisi (Yayımlanmamış yüksek lisans tezi). Atatürk Üniversitesi, Erzurum.

Ebrahim, A. (2012). The effect of cooperative learning strategies on elementary students' science achievement and social skills in Kuwait. International Journal of Science and Mathematics Education, 10(2), 293-314.

Eltem, Ö. (2018). Fen bilimlerinde maddenin yapısı ve özellikleri ünitesinin ögretiminde eğitsel oyunların kullanılması (Yayımlanmamış yüksek lisans tezi). Osmangazi Üniversitesi, Eskişehir.

Eryılmaz, A. ve Sencar, S., (2002). Öğrencilerin elektrik devreleri ile ilgili kavram yanılgılarında görülen cinsiyet farklılıklarının nedenleri. V.Ulusal Fen Bilimleri ve Matematik Eğitimi Kongresi,16-18 Eylül, ODTÜ, Ankara.

Espinoza-Morales, C. (2017). Learning electron transport chain process in photosynthesis using video and serious game (Yayımlanmamış doktora tezi). Purdue University, USA.

Eymur, G. ve Geban, Ö. (2016). The collaboration of cooperative learning and conceptual changes: Enhancing the students'understanding of chemical bonding concepts. International Journal of Science and Mathematics Education, 15(5), 853-871. doi.org/10.1007/s10763-016-9716-z

Fabian, K., Topping, K. J. ve Barron, I. G. (2018). Using mobile technologies for mathematics: Effects on student attitudes and achievement. Educational Technology Research and Development, 66, 11191139. doi.org/10.1007/s11423-018-9580-3.

Fırat, M. (2014). Maddenin yapısı ve özellikleri ünitesinin ögretiminde iki farklı işbirlikli ögrenme yönteminin ögrencilerin akademik başarlart ve epistemolojik tutumları üzerine etkisi (Yayımlanmamış yüksek lisans tezi). Atatürk Üniversitesi, Erzurum.

Fırat, S. (2011). Bilgisayar destekli eğitsel oyunlarla gerçekleştirilen matematik ögretiminin kavramsal ögrenmeye etkisi (Yayımlanmamış yüksek lisans tezi). Adıyaman Üniversitesi, Adıyaman.

Gallardo, J. R., Cirugeda, I. L. ve Rubio, C. M. (2012). Influence of cooperative learning on students' selfperception on leadership skills: A case study in science education. Higher Education Studies, 2(4), 40-48.

Geban, Ö., Ertenpınar, H. ve Sönmez, G. (2002). Altıncı sinıf öğrencilerinin elektrik konusundaki kavramlar anlamalarında kavramsal değişim yaklaşımının etkisi. V.Ulusal Fen Bilimleri ve Matematik Eğitimi Kongresi, 16-18 Eylül. ODTÜ, Ankara.

Genç, M. (2016). An evaluation of the cooperative learning process by sixth-grade students. Research in Education, 95(1), 19-32. doi: 10.7227/RIE.0018

Gençer, S. (2017). Eğitsel oyunlarla hazırlanmış ortaokul 7. sınıf "Yaşamımızdaki Elektrik" ünitesinin ögretiminin öğrenci başarısına etkisi (Yayımlanmamış yüksek lisans tezi). Amasya Üniversitesi, Amasya

Gençer, S. ve Karamustafaoğlu, O. (2014). "Durgun Elektrik" konusunun eğitsel oyunlarla öğretiminde öğrenci görüşleri. Araştırma Temelli Etkinlik Dergisi (ATED), 4(2), 72-87.

Ghufron, M. A. ve Ermawati, S. (2018). The strengths and weaknesses of cooperative learning and problembased learning in efl writing class: Teachers and students' perspectives. International Journal of Instruction, 11(4), 657-672. https://doi.org/10.12973/iji.2018.11441a.

Gillies, R. M. (2006). Teachers' and students' verbal behaviours during cooperative and small group learning. British Journal of Educational Psychology, 76(2), 271-287.

Goudas, M. ve Magotsiou, E. (2009). The effects of a cooperative physical education program on students' social skills. Journal of Applied Sport Psychology, 21, 356-364.

Göktaş, E. (2017). Eğitim politikası bağlamında işbirlikli ögrenme ve geleneksel ögrenme yöntemlerinin başarı ve tutuma etkisinin meta analitik biçimde incelenmesi (Yayımlanmamış doktora tezi). Marmara Üniversitesi, İstanbul.

Gülsoy, T. (2013). 6. sını öğrencilerinin kelime hazinesinin geliştirilmesinde eğitsel oyunların etkisi (Yayımlanmamış yüksek lisans tezi). Niğde Üniversitesi, Niğde.

Gürpınar, C. (2017). Fen bilimleri öğretiminde eğitsel oyun destekli ögretim uygulamalarının ögrenme ürünlerine etkisi (Yayımlanmamış yüksek lisans tezi). Kırıkkale Üniversitesi, Kırıkkale.

Hardal, Ö. ve Eryılmaz, A. (2002). Basit araçlarla ve yaparak ögrenme yöntemine göre geliştiren elektrik devreleri ile ilgili etkinlikler. V.Ulusal Fen Bilimleri ve Matematik Eğitimi Kongresi, 16-18 Eylül. ODTÜ, Ankara.

Harris, K., Marcus, R., McLaren, K. ve Fey, J. (2001). Curriculum materials supporting problem-based teaching. School Science ve Mathematics, 101(6), 310-318.

Harvey, M. M. (2018). Video games and virtual reality as classroom literature: Thoughts, experiences, and 
learning with 8th grade middle school students (Unpublished doctoral dissertation). University of New Mexico, USA.

Hazar, M. (2005). Beden eğitimi ve sporda oyunla eğitim. Ankara: Tutibay Yayıncılık.

Hennessy, D. ve Evans, R. (2006). Small-group learning in the community college classroom. The Community College Enterprise, 12(1), 93-110.

Huang, T. C., Huang, Y. M. ve Yu, F. Y. (2011). Cooperative weblog learning in higher education: Its facilitating effects on social interaction, time lag, and cognitive load. Educational Technology ve Society, 14(1), 95-106.

Hung, H. T., Yang, J. C., Hwang, G. J., Chu, H. C. ve Wang, C. C. (2018). A scoping review of research on digital game-based language learning. Computers ve Education, 126, 89-104. doi: 10.1016/j.compedu.2018.07.001

İyi, E. (2018). Farklı işbirlikli öğrenme yöntemlerinin fen bilimleri ögretmen adaylarının akademik başarı ve epistemolojik inançlarl üzerine etkisi (Yayımlanmamış yüksek lisans tezi). Atatürk Üniversitesi, Erzurum.

Johnson, D. W. ve Johnson, R.T. (1989). Cooperation and competition: Theory and research. Edina, Minnesota: Interaction Book Company.

Johnson, D. W., Johnson, R. T. ve Stanne, M. B. (2000). Cooperative learning methods: A meta-analysis. University of Minnesota, Minneapolis, Minnesota.

Kagan, S. (1994). Cooperative learning. Cordillera: Kagan.

Kagan, S. ve Kagan, M. (2009). Kagan cooperative learning. Kagan Publishing.

Kaptan, F. ve Korkmaz, H. (1999). Ilköğretimde fen bilgisi ögretimi. Ankara: Anı Yayıncılık.

Karamustafaoğlu, O. ve Kaya, M. (2013). Eğitsel oyunlarla "Yansıma ve Aynalar" konusunun öğretimi: Yansımalı koşu örneği. Araştırma Temelli Etkinlik Dergisi, 3(2), 41-49.

Kaya, S. ve Elgün, A. (2015). Eğitsel oyunlar ile desteklenmiş fen öğretiminin ilkokul öğrencilerinin akademik başarısına etkisi. Kastamonu Eğitim Dergisi, 23(1), 329-342.

Kılıç, Y. (2016). İşbirlikli öğrenme yönteminin 5. sınıf ögrencilerinin fen bilimleri dersi Vücudumuzun Bilmecesini Çözelim ünitesinde sahip olduklart kavram yanılgılarını gidermedeki etkisi (Yayımlanmamış yüksek lisans tezi). Gazi Üniversitesi, Ankara.

Kibirige, I. ve Lehong, M. J. (2016). The effect of cooperative learning on grade 12 learners' performance in projectile motions, South Africa. EURASIA Journal of Mathematics, Science ve Technology Education, 12(9), 2543-2556. DOI: https://doi.org/10.12973/eurasia.2016.1250a

Kocayörük, A. (2000). Illkögretim ögrencilerinin sosyal becerilerini geliştirmede dramanın etkisi
(Yayımlanmamış yüksek lisans tezi). Ankara Üniversitesi, Ankara, Türkiye.

Koç, Y. (2014). Fen ve teknoloji ögretmenlerinin işbirlikli ögrenme modeli hakkında bilgilendirilmesi, bu modeli sinufta uygulamalar ve elde edilen sonuçların değerlendirilmesi: Ăgrı il örneği (Yayımlanmamış doktora tezi). Ankara Üniversitesi, Ankara.

Koçyiğit, S., Tuğluk, M. N. ve Kök, M. (2007). Çocuğun gelişim sürecinde eğitsel bir etkinlik olarak oyun. Atatürk Üniversitesi Kazım Karabekir Eğitim Fakültesi Dergisi, 16, 324-342.

Koka, V. (2018). Sosyal bilgiler dersinde kullanilan bilgisayar destekli eğitsel oyunların ögrencilerin ders başarısına olan etkisi. (Yayımlanmamış yüksek lisans tezi). nönü Üniversitesi, Malatya.

Kuşakçı-Ekim, F. (2007). Illköğretim fen öğretiminde kavramsal karikatürlerin ögrencilerin kavram yanılgılarını gidermedeki etkisi (Yayımlanmamış yüksek lisans tezi). Ankara Üniversitesi, Ankara.

Leikin, R. ve Zaslavsky, O. (1997). Facilitating student interactions in mathematics in a cooperative learning setting, 350. Journal of Research in Mathematics Education, 28(3), 331-359.

Little, T. W. (2015). Effects of digital game-based learning on student engagement and academic achievement (Unpublished doctoral dissertation). Lamar University, USA.

Madden, N. A. ve Slavin, R. E. (1983). Effects of cooperative learning on the social acceptance of mainstreamed academically handicapped students. Journal of Special Education, 17, 171-182.

Mangır, M. (1993). Çocuğun gelişiminde oyunun önemi. Yasadıkça Eğitim, 26(16), 14-19.

Martin, M. W. (2012). Serious game design principles: The impact of game design on learning outcomes (Unpublished doctoral dissertation). Old Dominion University, USA

Martinez-Hernandez, K. (2010). Development and assessment of a chemistry-based computer video game as a learning tool (Unpublished doctoral dissertation). Purdue University, USA.

McCall, M. O. (2017). The effects of individual versus cooperative testing in a flipped classroom on the academic achievement, motivation toward science, and study time for $9^{\text {th }}$ grade biology students (Unpublished doctoral dissertation). University of South Alabama, USA.

Mcmillan, J. H. ve Schumacher, S. (2006). Research in education: Evidence-based inquiry. Sixth Edition. Boston, MA: Allyn and Bacon.

Mezei, J. M. (2015). Science teachers' perceptions of the relationship between game play and inquiry learning (Unpublished doctoral dissertation). Columbia University, USA. 
Milli Eğitim Bakanlığı (2013). İlköğretim kurumları (ilkokullar ve ortaokullar) fen bilimleri dersi $(3,4,5$, 6, 7 ve 8. sinıflar) öğretim programı. (14.03.2015’te erişilmiştir.),

http://mufredat.meb.gov.tr/Dosyalar/2018123123119 37FEN\%20B\%C4\%B0L\%C4\%B0MLER\%C4\%B0 $\% 20 \% \mathrm{C} 3 \% 96 \% \mathrm{C} 4 \% 9 \mathrm{ERET} \% \mathrm{C} 4 \% \mathrm{~B} 0 \mathrm{M} \% 20 \mathrm{PROG}$ RAMI2013.pdf

Mutlu-Bayraktar, D. ve Camnalbur, M. (2018). İşbirlikli öğrenmenin akademik başarı üzerine etkisi: bir meta-analiz çalışması. Insan ve Toplum Bilimleri Araștırmaları Dergisi, 7(2), 1149-1172. doi: 10.15869/itobiad.378623

National Academy of Sciences. (2006). Rising above the gathering storm: Energizing and employing America for a brighter economic future. Washington, DC: National Academy of Sciences/ National Academy of Engineering/Institute of Medicine. (11.06.2015'te erişilmiştir.),

https://www.nap.edu/catalog/11463/rising-abovethe-gathering-storm-energizing-and-employingamerica-for

Neimeyer, S. A. (2006). An examination of the effects of computer-assisted educational games on student achievement (Unpublished doctoral dissertation). University of Houston-Clear Lake, USA.

Nunes, P. S., Soares, A. A. ve Catarino, P. (2018). Efeitos da construção de um jogo educativo de matemática nas atitudes e aprendizagem alunos: estudo de caso (Effects of the construction of an educational mathematics game on students' attitudes and learning: case study). Revista Iberoamericana sobre Calidad, Eficacia y Cambio en Educación, 16(4), 521.

Önen, F., Demir, S. ve Şahin, F. (2012). Fen öğretmen adaylarının oyunlara ilişkin görüşleri ve hazırladıkları oyunların değerlendirilmesi. Ahi Evran Üniversitesi Kirşehir Eğitim Fakültesi Dergisi (KEFAD), 13(3), 299-318.

Öztürk, B. (2017). Maddenin tanecikli yapısının ögretiminde iyi bir ĕgitim ortamı için yedi ilke ve modellerle desteklenen işbirlikli ögrenme yöntemlerinin uygulanması (Yayımlanmamış doktora tezi). Atatürk Üniversitesi, Erzurum.

Pehlivan, H. (2014). Oyun ve ögrenme (4. Bask1). Ankara: Anı Yayınları.

Perkins, A. C. (2016). Earthquake: Game-based learning for 21st century STEM education (Yayımlanmamış doktora tezi). Texas A \& M University.

Piaget, J. (1962). Play, dreams and imitation in childhood. Newyork: Norton.

Rabgay, T. (2018). The Effect of using cooperative learning method on tenth grade students' learning achievement and attitude towards biology. International Journal of Instruction, 11(2), 265-280. https://doi.org/10.12973/iji.2018.11218a.

Reynolds-Perez, C. (2017). Experiences of middle and high school AVID students from an urban south Texas school district who played college ready-the game. (Unpublished doctoral dissertation). ProQuest Dissertations and Theses veri tabanından erişilmiştir. (UMI No.10641631).

Rouse, K. E. (2013). Gamification in science education: The relationship of educational games to motivation and achievement. (Unpublished doctoral dissertation). The University of Southern Mississippi, USA.

Saracaloğlu, A. S. ve Aldan-Karademir, Ç. (2009). Ĕgitsel oyun temelli fen ve teknoloji ögretiminin ögrenci başarısına etkisi. VIII. Ulusal Sınıf Öğretmenliği Eğitimi Sempozyumu, Bildiri Kitabı. 21-23 Mayıs 2009. Osmangazi Üniversitesi: Eskişehir. 10981107.

Say, S. ve Bağ, H. (2017). The Evaluation of the effect of a newly designed computer game on $7^{\text {th }}$ grade students' motivation towards science and aggression. EURASIA Journal of Mathematics Science and Technology Education, 13(8), 53795393. doi. 10.12973/eurasia.2017.00831a

Senemoğlu, N. (2005). Gelişim ve öğrenme. Ankara: Gazi Kitapevi.

Shapiro, M. (2016). Evaluating the efficacy of a chemistry video game (Unpublished doctoral dissertation). Towson University, USA.

Shekarey, A. (2012). Effects of cooperative learning on the development of students' social skills. Education Strategies in Medical Sciences, 5(1), 31-37.

Siegel, C. (2005). An ethnographic inquiry of cooperative learning implementation. Journal of School Psychology, 43(3), 219-239.

Slavin, R. E. (1991). Group rewards make groupwork work. Educational Leadership, 48(5), 89-91.

Slavin, R. E. (1992). When and why does cooperative learning increase achievement? Theoretical and empirical perspectives. Hertz-Lazarowitz \& Miller (Ed.) Interaction in Cooperative Groups içinde (s.145-173). NY: Cambridge University Press.

Smith, K., Johnson, D. W. ve Johnson, R. T. (1981). Can conflict be constructive: Controversy versus concurrence seeking in learning groups. Journal of Educational Psychology, 73, 651-663.

Stewart, P. M., Jr. (2013). Learning the rules of the game: The nature of game and classroom supports when using a concept-integrated digital physics game in the middle school science classroom (Unpublished doctoral dissertation). Columbia University, USA.

Şaşmaz-Ören, F. ve Erduran-Avcı, D. (2004). Eğitimsel oyunla öğretimin fen bilgisi dersi "güneş sistemi ve gezegenler" konusunda akademik başarı üzerine etkisi. Ondokuz Mayıs Üniversitesi Ĕgitim Fakültesi Dergisi, 18, 67-76.

Şimşek, U., Şimşek, Ü. ve Doymuş, K. (2006). İşbirlikçi öğrenme yöntemi üzerine derleme çalışması III. İşbirlikçi öğrenme yönteminin eğitim ortamındaki 
faydaları. Kazım Karabekir Eğitim Fakültesi Dergisi, 13, 414-430.

Şimşek, Ü. (2007). Çözeltiler ve kimyasal denge konularında uygulanan jigsaw ve birlikte ögrenme tekniklerinin ögrencilerin maddenin tanecikli yapıda ögrenmeleri ve akademik başarıları üzerine etkisi.

Tortumluoğlu, Y. (2014). Işsbirlikli öğrenme modelinin fen ve teknoloji dersinde öğrenci başarlsina etkisi: Ardahan ili örneği (Yayımlanmamış yüksek lisans tezi). Atatürk Üniversitesi, Erzurum.

Tsai, Y. L. ve Tsai, C. C. (2018). Digital game-based second-language vocabulary learning and conditions of research designs: A meta-analysis study. Computers ve Education, 125, 345-357. doi.org/10.1016/j.compedu.2018.06.020

Tuan, H. L., Chin, C. C. ve Shieh, S. H. (2005). The development of a questionnaire to measure students' motivation towards science learning. International Journal of Science Education, 27(6), 634-659.

Turgut, S. ve Turgut, İ. G. (2018). The effects of cooperative learning on mathematics achievement in Turkey: A meta-analysis study. International Journal of Instruction, 11(3), 663-680. Doi 10.12973/iji.2018.11345a

Uzuntiryaki, E., Çakır, H. ve Geban, Ö. (2001). Kavram haritalarl ve kavramsal değişim metinlerinin ögrencilerin "Asit-Bazlar" konusundaki kavram yanılgılarının giderilmesine etkisi. Yeni Bin Y1lın Basında Fen Bilimleri Eğitimi Sempozyumu, (7-8 Eylül 2001), İstanbul. Bildiriler Kitabı, 281-284, 2001 Maltepe Üniversitesi Eğitim Fakültesi.

Webb, N. M. (1980). An analysis of group interaction and mathematical errors in heterogeneous ability groups. British Journal of Educational Psychology, 50(3), 266-276

Webb, N. M., Sydney, H. ve Farivor, A. M. (2002). Theory into practice. College of Education, 41(1) 13-20.

Wyman, P. J. (2018). Academic achievement with cooperative learning using homogeneous and heterogeneous groups (Unpublished doctoral dissertation). Liberty University, USA.

Yeşilkaya, İ. (2013). 7. sınıf sosyal bilgiler dersi "Zaman İçinde Bilim" ünitesinin eğitsel oyun yöntemi ile ögretimi (Yayımlanmamış yüksek lisans tezi). Yükseköğretim Kurulu Ulusal Tez Merkezi'nden edinilmiştir. (Tez No. 326663)
(Yayımlanmamış doktora tezi). Atatürk Üniversitesi, Erzurum, Türkiye.

Toprac, P. K. (2008). The effects of a problem -based learning digital game on continuing motivation to learn science (Unpublished doctoral dissertation). The University of Texas, USA.

Yılar, M. B. (2015). Sosyal bilgiler dersinde işbirlikli ögrenme yöntemlerinin öğrencilerin akademik başarlarına, demokratik tutumlarına ve sosyal becerilerine etkileri (Yayımlanmamış doktora tezi). Atatürk Üniversitesi, Erzurum.

Yıldı, E. (2019). 5, 6, 7. sinıf fen bilimleri dersinde yaşanan öğrenme problemlerinin giderilmesinde eğitsel oyun, okuma-yazma-oyun ve okuma-yazmauygulama yöntemlerinin etkisinin incelenmesi. (Yayımlanmamış doktora tezi). Atatürk Üniversitesi, Erzurum.

Yıldız, E., Şimşek, Ü. ve Ağdaş, H. (2017). Eğitsel oyun entegre edilmiş grup araştırması yönteminin öğrencilerin fen öğrenimi motivasyonları ve sosyal becerileri üzerine etkisi. Kırşehir Eğitim Fakültesi Dergisi, 18(2), 37-54.

Yıldız, E., Şimşek, Ü. ve Ağdaş, H. (2018). The effects of educational game-integrated group research method on academic achievement, attitude towards school, and retention of knowledge in teaching regulatory system. Journal of Turkish Science Education, 15(3), 91-105.

Yıldız, E., Şimșek, Ü. ve Aras, H. (2016). Dolaşım sistemi konusunda eğitsel oyun yönteminin kullanılmasının öğrencilerin akademik başarı ve fen öğrenimi motivasyonu üzerine etkisi. Mustafa Kemal Üniversitesi Sosyal Bilimler Enstitüsü Dergisi, 13(36), 20-32.

Yılmaz, H. ve Çavaş, P. H. (2007). Reliability and validity study of the Students' Motivation toward Science Learning (SMTSL) Questionnaire. Elementary Education Online, 6(3), 430-440.

Zentall, S. S., Kuester, D. A. ve Craig, B. A. (2011). Social behavior in cooperative groups: Students at risk for ADHD and their peers. Journal of Educational Research, 104(1), 28-41.

Zheng, M. (2012). Fifth graders' flow experience in a digital game-based science learning environment. International Journal of Virtual and Personal Learning Environments (IJVPLE), 5(2), 69-86. 
Ek-1: Etik Kurul Onayı

T.C.

ATATÜRK ÜNİVERSITESI

SOSYAL VE BEŞERI BILIMLER ETIK KURULU

Eğitim Bilimleri Birim Etik Kurulu Karar Formu

\begin{tabular}{|c|c|}
\hline & $\begin{array}{l}\text { Toplantı Sayısı: } 08 \\
\text { Karar No: } 17 \\
\end{array}$ \\
\hline 舜 & $\begin{array}{l}\text { Aşağıda bilgileri verilen araştırma makalesi ile ilgili çalışmanın, etik ilkeler açısından } \\
\text { değerlendirilmesi isteği ile ilgili husus görüşüldü. } \\
\text { Yapılan görüşmelerden sonra; söz konusu araştırma makalesi ile ilgili yapılacak çalışma } \\
\text { için, araştırmanın gerekçe, amaç, yaklaşım ve yöntemleri dikkate alınarak konuyla ilgili } \\
\text { çalışmanın gerçekleştirilmesinde etik ve bilimsel yönden sakınca bulunmadığna, Etik } \\
\text { Kurulu oy birliği ile karar vermiştir. }\end{array}$ \\
\hline 胥茎 & $\begin{array}{l}\text { Proje Yürütücüsü: Arş. Gör. Dr. Emre YILDIZ, Arş. Gör. Şeyma ÇALIKLAR, Prof. Dr. } \\
\text { Ümit ŞIMŞEK ve Özlem AGGGÜL } \\
\text { Çalışma Konusu: Eğitsel Oyun ve İşbirlikli Öğrenmenin 6.Sınıf Öğrencilerinin } \\
\text { Akademik Başarıları, Sosyal Becerileri ve Ögrenme Motivasyonlarına Etkisi }\end{array}$ \\
\hline
\end{tabular}

\begin{tabular}{|l|l|}
\hline \multicolumn{2}{|c|}{ EĞiTiM BİLiMLERİ BIRIM ETIK KURULU } \\
\hline Prof. Dr. Muhsine BÖREKÇİ & Etik Kurul Başkanı \\
\hline Prof. Dr. Ali Osman ENGIN & Etik Kurul Başkan Yardımcısı \\
\hline Prof. Dr. Betül ASLAN & Etik Kurul Üyesi \\
\hline Prof. Dr. İhsan Sabri BALKAYA & Etik Kurul Üyesi \\
\hline Prof. Dr. Mustafa CİHAN & Etik Kurul Raportörü \\
\hline
\end{tabular}

